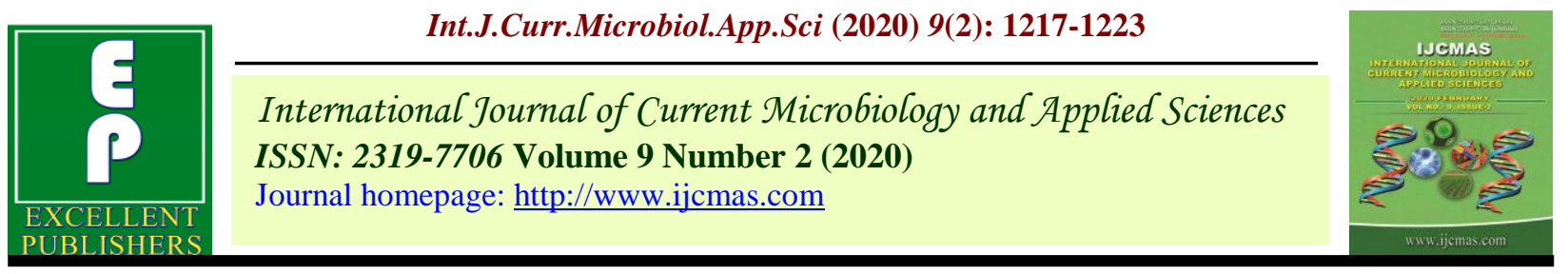

Original Research Article

https://doi.org/10.20546/ijcmas.2020.902.144

\title{
Socio-Economic Conditions of Farmers in Rice-Fallow Area of Bhagalpur District of Bihar, India
}

\author{
Nitu Kumari* and P. S. Badal \\ Department of Agricultural Economics, Institute of Agricultural Sciences, Banaras Hindu \\ University, Varanasi, Uttar Pradesh, 221005, India \\ *Corresponding author
}

A B S T R A C T

Keywords

Rice-fallow, Socioeconomic condition, Kharif fallow, Bhagalpur, Area, Constraints

Article Info

Accepted:

08 January 2020

Available Online:

10 February 2020
About 30\% (11.7 mha) of the area under rice production during kharif season in India remain fallow in the subsequent rabi due to number of biotic, abiotic and socioeconomic constrains. . In Bhagalpur district of Bihar approximately 39.89 per cent of the area remains fallow after kharif rice cultivation. The present study was conducted in Bhagalpur district of Bihar with the objective to study the socio-economic conditions of farmers in rice fallow area. Simple random sampling method was used to select village, block and respondents. The primary data was collected through interview method by contacting the respondent of the village.

\section{Introduction}

In India, rice is cultivated across the length and width of the country occupying about 43.39 million hectares area under four major eco systems i.e. irrigated ( 21 million ha), rain fed lowland (14.2 million ha), rain fed upland (6.3 million ha) and flood-prone (3.1 million ha) with total production of 104.32 million tones and average productivity of $2.4 \mathrm{t} \mathrm{ha}^{1}$. Whereas in Bihar Rice is cultivated in 3.21 million hectares with total production of 6.49 million tonnes (DAC\&FW 2016). In irrigated areas, rice-wheat, rice-rice, rice-sugarcane, rice-groundnut, rice-vegetables and rice- mustard are important crop rotations whereas in rain fed areas, rice-pulses, rice-sunflower, rice-sesame and rice-fallows are prevalent. Rice is the principal crop during kharif (rainy) season in India. The crop occupies an area of over 40 million ha. This area is not fully utilized for crop production in the subsequent rabi (post rainy) season; about 12 million ha remains fallow (Subbarao et al., 2001). This unutilized area offers enormous opportunities to overcome the problem of food and nutritional insecurity. Accomplishing household food security remains the primary concern though at the national level India has piled up a huge stock (about 60 million $\mathrm{t}$ ) of 
food grains, mainly rice and wheat. Food crops such as pulses and oilseeds are critical to food security. Nutritional security is equally important; about $30 \%$ of the population suffer from malnutrition (Kumar and Ghosh, 2013).

About 30\% (11.7 mha) of the area under rice production during kharif season in India remain fallow in the subsequent rabi due to number of biotic, abiotic and socioeconomic constrains. Despite of ample opportunities rice fallow systems have been bypassed in the research and developments for a numbers of constraints. Major rice fallow area $(82 \%)$ is concentrated on eastern parts of the country. States with larger area of rice-fallows are Chhattisgarh, Madhya Pradesh, Jharkhand, Bihar, West Bengal and Orissa the remaining $18 \%$ area in the states like Tamil Nadu, Karnataka and Andhra Pradesh and there exists a large scope for expansion of area under pulse crops. Short duration pulses are ideal candidates for their cultivation in such areas (Bourai et al., 2002). . The existing rice fallow area $(11.7 \mathrm{~m} \mathrm{ha})$ is almost equivalent to the net sown area of Punjab, Haryana and western Uttar Pradesh -the sheet of green revolution in India. If this area is brought under cultivation it may usher another green revolution in India benefiting millions of farmers. Promotion of pulses crops in the existing fallow area would also improve sustainability of the rice production system besides enhancing production and augmenting income. It should be considered appropriate to identify abiotic, biotic and socio-economic constraints to rabi cropping that can be addressed through technological and policy intervention.

There are various reasons that lead to remain the land fallow after rice cultivation. Some of them are lack of irrigation, highly variable and inadequate monsoon rains, very low profitability of winter rains, low soil moisture in surface layer after harvest of rice, water stagnation / excessive moisture in November/December, soil compaction and cracks in vertisols, cultivation of long duration rice varieties, lack of appropriate varieties of winter crops for late planting lack of public awareness, research and development efforts and policy support and stray cattle.

\section{Materials and Methods}

The study was conducted in Bhagalpur district of Bihar. The Bihar state was purposively selected for the present study as it has $36.8 \%$ of total kharif rice fallow areas. The Bhagalpur district is purposively selected for the present study as the main crop cultivated in this region is rice and it has vast area under rice fallows. Bhagalpur district consists of 16 blocks viz., (i)Pirpainti (ii) Kahalgaon (iii) Sanhaula (iv) Sabaur (v)Nathnagar (vi) Jagdishpur (vii) Sultanganj (viii) Sahkund (ix) Bihpur (x) Navgachia (xi) Gopalpur (xii) Kharik (xiii) Narayanpur (xiv) Gauradih (xv) Ismailpur and (xvi) Rangrachowk.

Out of these 16 blocks, Sultanganj block has been purposively selected for the study as the main occupation of the people in this region is agriculture and main crop cultivated in this region is rice crop.

From the selected developmental block, a list of all the villages was prepared and five villages were randomly selected using random table with replacement method. These selected villages are given below:

1. Khanpur Daulatpur

2. Akbarnagar

3. Rasidpur

4. Khanpur

5. Udhadih 
From the selected villages the list of farmers growing rice was prepared and was prepared and further classified into four size groups based on their size of holdings viz.

Marginal farmer (having $<1.25$ acres wetland and $<2.5$ acres dryland)

Small farmer (having 1.25-2.5 acres of wetland and 2.5-5.0 acres dryland)

Medium farmer (5-10 acres holding) and

Large farmer(>10 acres).

From each size group farmers were selected from each village by simple random sampling method. Thus ultimate sample size was 50 respondents which comprised of marginal, small, medium and large farmer. There are 23 marginal, 14 small, 9 medium and 4 large farmers.

The data required for this study was primary in nature. However, the secondary data are pertained to the latest one available in the Department of Agriculture, government of Bihar, Bhagalpur. The primary data was collected through interview method by contacting the respondent of the village. The pre-tested schedule was used for data collection on following aspects:Socioeconomic conditions of the farmer (age, gender, education, number of family members, farm holding size, etc.).

\section{Results and Discussion}

\section{Classification of sample farmers on the basis of land holding}

In the study area, all the sample farmers were male. Table 1 represents the distribution of sample farmers according to land holding size. Out of total sample size, 42 per cent farmers belong to marginal category of farmers having less than one hectare of agricultural land. 32 per cent sample farmers were belong to small category of farmers. The shares of medium and large farmers in total sample farmers were 16 and 10 per cent respectively (Table 1 ).

\section{Age-wise distribution of sample farmers}

The age-wise distribution of sample farmers is presented in Table 2. In case of marginal farmers , 14.28 per cent farmers were belong to $18-30$ years age group, 28.57 per cent sample farmers were belong to $31-50$ years and remaining 57.14 per cent sample farmers belong to 51 and above years age group. In case of small farmers, 12.50 per cent farmers were belong in the category of 18-30 year age group. 43.75 per cent sample farmers belong to age category of $31-50$ years and 51 and above age group. In case of medium category farmers, distribution of sample farmers in age group of 18-30, 31-50 and above 51 year age group was one, three and four respectively. In case of large farmers, two sample farmers belong to the age group of 31-50 years and three farmers belong to 51 and above age group.

\section{Literacy level of the sample farmers}

The literacy level of the sample respondents is presented in Table 3. The highest literacy level was obtained in case of large category of farmers. In case of marginal farmer, 52.38 per cent respondents were literate and remaining 47.61 per cent sample farmers were illiterate. In case of small category farmers, the literate and illiterate respondents were 56.25 and 43.75 per cent respectively, whereas in case of medium farmers it was 62.50 and 37.50 per cent respectively.

\section{Occupation of the sample farmers}

The occupation wise distribution of respondent sample was presented in table 4 . In case of marginal farmers, the main 
occupation of 80.95 per cent sample farmers was crop product only. 4.76 per cent sample farmers doing crop production along with dairy production to enhance the income and remaining 9.52 per cent farmers were doing crop production and business and remaining farmers doing other works.

In case of small farmers, eleven respondents doing crop production only, two farmers doing crop and livestock production, one farmer respondent doing crop production along with service and two farmers were involved in crop production and business. In case of medium farmers, 62.50 per cent respondents doing crop production only, whereas in case of large farmers it was 40 per cent (Table 4).

\section{Average family size of respondents}

Table 5 represents average family size of the sample respondents. It is clear from the Table 5 that marginal and small farmers having large family size whereas medium and large farmers having small family size. The average family size for marginal, small, medium and large farmers were $11,9,11$, and 13. Although in all categories of farmers there are more than 10 members but in case of medium and large farmers there are big and joint families therefore more number of members.

Table.1 Classification of the Farmers According to Land Holding Size

\begin{tabular}{|l|c|c|c|c|c|}
\hline Farmer & Marginal & Small & Medium & Large & Total \\
\hline Number & 21 & 16 & 8 & 5 & 50 \\
\hline Percentage & 42 & 32 & 16 & 10 & 100 \\
\hline
\end{tabular}

*source - compiled from field study

Table.2 Age-wise classification of sample farmers

\begin{tabular}{|l|c|c|c|c|c|}
\hline Age Group & Marginal & Small & Medium & Large & Total \\
\hline $\mathbf{1 8 - 3 0}$ & $3(14.28)$ & $2(12.50)$ & $1(12.50)$ & $0(0)$ & $6(12)$ \\
\hline $\mathbf{3 1 - 5 0}$ & $6(28.57)$ & $7(43.75)$ & $3(37.50)$ & $2(40)$ & $18(36)$ \\
\hline $\mathbf{5 1}$ and above & $12(57.14)$ & $7(43.75)$ & $4(50)$ & $3(60)$ & $26(52)$ \\
\hline TOTAL & $21(100)$ & $16(100)$ & $8(100)$ & $5(100)$ & 50 \\
\hline Percentage & 42 & 32 & 16 & 10 & 100 \\
\hline
\end{tabular}

*Source - compiled from field survey

Table.3 Literacy Level of the Farmers

\begin{tabular}{|l|c|c|c|c|c|}
\hline Particulars & Marginal & Small & Medium & Large & Total \\
\hline Literate & $11(52.38)$ & $9(56.25)$ & $5(62.50)$ & $4(80)$ & 29 \\
\hline Illiterate & $10(47.61)$ & $7(43.75)$ & $3(37.50)$ & $1(20)$ & 21 \\
\hline Total & $21(100)$ & $16(100)$ & $8(100)$ & $5(100)$ & 50 \\
\hline Percentage & 42 & 32 & 16 & 10 & 100 \\
\hline
\end{tabular}

*source- compiled from field survey 
Table.4 Occupation of the Sample Farmers

\begin{tabular}{|c|c|c|c|c|c|c|}
\hline Occupation & Marginal & Small & Medium & Large & Total & Percentage \\
\hline $\begin{array}{l}\text { Agriculture } \\
\text { only }\end{array}$ & $\begin{array}{c}17 \\
(80.95)\end{array}$ & $\begin{array}{c}11 \\
(68.75)\end{array}$ & $\begin{array}{c}5 \\
(62.50)\end{array}$ & $\begin{array}{c}2 \\
(40)\end{array}$ & 35 & 70 \\
\hline $\begin{array}{l}\text { Agriculture } \\
\text { and Dairy }\end{array}$ & $\begin{array}{c}1 \\
(4.76)\end{array}$ & $\begin{array}{c}2 \\
(12.50)\end{array}$ & $\begin{array}{c}1 \\
(12.50)\end{array}$ & $\begin{array}{c}1 \\
(20)\end{array}$ & 5 & 10 \\
\hline $\begin{array}{l}\text { Agriculture } \\
\text { and Service }\end{array}$ & $\begin{array}{c}0 \\
(0)\end{array}$ & $\begin{array}{c}1 \\
(6.25)\end{array}$ & $\begin{array}{c}1 \\
(12.50)\end{array}$ & $\begin{array}{c}1 \\
(20)\end{array}$ & 3 & 6 \\
\hline $\begin{array}{l}\text { Agriculture } \\
\text { and Business }\end{array}$ & $\begin{array}{c}2 \\
(9.52)\end{array}$ & $\begin{array}{c}2 \\
(12.50)\end{array}$ & $\begin{array}{c}1 \\
(12.50)\end{array}$ & $\begin{array}{c}0 \\
(0)\end{array}$ & 5 & 10 \\
\hline Others & $\begin{array}{c}1 \\
(4.76)\end{array}$ & $\begin{array}{c}0 \\
(0)\end{array}$ & $\begin{array}{c}0 \\
(0)\end{array}$ & $\begin{array}{c}1 \\
(20)\end{array}$ & 2 & 4 \\
\hline Total & 21 & 16 & 8 & 5 & 50 & 100 \\
\hline
\end{tabular}

*source- compiled from field survey

Table.5 Family Size for Different Categories of Farmers

\begin{tabular}{|l|c|c|c|c|c|}
\hline Particulars & Marginal & Small & Medium & Large & Total \\
\hline 1-2 members & 1 & 0 & 0 & 0 & 1 \\
\hline 3-5 members & 5 & 4 & 1 & 1 & 11 \\
\hline 6-10 members & 6 & 7 & 6 & 2 & 21 \\
\hline $\begin{array}{l}10 \quad \text { and more } \\
\text { members }\end{array}$ & 9 & 5 & 1 & 2 & 17 \\
\hline Average family size & 11 & 9 & 11 & 13 & 50 \\
\hline
\end{tabular}

*source- compiled from field survey

Table.6 Land Holding of Different Categories of Sample Farmers

\begin{tabular}{|l|c|c|c|c|}
\hline Particulars & \multicolumn{4}{|c|}{ Size of farm (in hectares) } \\
\hline Numbers & Marginal $(<2.5)$ & Small (2.5-5) & Medium (5-10) & Large (>10) \\
\hline Area(per farmer) & 1.06 & 3.17 & 7.12 & 15.6 \\
\hline Total area & 22.45 & 50.75 & 57 & 78 \\
\hline
\end{tabular}

*source- compiled from field survey.

\section{Land holding size}

Table 6 indicated that average land holding of large and medium farmers were 15.6 and 7.12 hectares respectively whereas in case of marginal and small farmers it was only 1.06 and 3.17 hectares. In the above study it indicates that medium and large farmers having large size of holding whereas marginal and small farmers having small land holding.
It can be concluded that all the respondents of the current study were male members. The different categories of farmers according to land holding were marginal, small, medium, and large. Their percentage were respectively $21,16,8$ and 5 which indicates that there was large numbers of marginal and small farmers and very less numbers of medium and large farmers. The study revealed that more than $52 \%$ of farmers were of age above 50 while 
$36 \%$ of the farmers correspond to $31-50$ age group and $12 \%$ of farmers were under age group of 18-30 years. It can also be concluded that $58 \%$ of the farmers were literate while $42 \%$ are illiterate. It also showed that large and medium farmers were mostly literate. It can also be inferred that $70 \%$ of the farmers were depended on agriculture only while $10 \%$ farmers depended on agriculture and dairy, $6 \%$ agriculture and service, $10 \%$ agriculture and business while others category involved $4 \%$ only. Study also revealed that most of the marginal and small farmers depended upon agriculture only. The study also showed that marginal and small farmers having large family size, whereas medium and large farmers having small family size. It can also be inferred from the study that farm area availability per farmer for marginal farmer was 1.06 hectare while for small and medium sized farmers it was 3.17 and 7.12 hectares respectively and for large farmers area per farmer was 15.6 hectares.

\section{References}

Bourai, V. A., Joshi, K. D., and Khanal, N. 2002. Socioeconomic Constraints and Opportunities in Rainfed Rabi Cropping in Rice Fallow Areas of Nepal. ICRISAT, Patancheru, AP, India.

DAC\&FW 2016. Operational Guideline for Targeting Rice Fallow Areas, Department of Agriculture, Cooperation and Farmers Welfare, Ministry of Agriculture and Farmers Welfare, Government of India.

Gumma, M. K., Thenkabail, P. S., Teluguntla, P., Rao, M. N., Mohammed, I. A., and Whitbread, A. M. 2016. Mapping ricefallow cropland areas for short-season grain legumes intensification in South Asia using MODIS $250 \mathrm{~m}$ time-series data. International Journal of Digital Earth, 9(10), 981-1003.

Gurumurthy, P., and Rao, M. 2006. Effect of tillage and irrigation regimes on soil physical properties and performance of sunflower in rice fallow I. Soil physical properties and crop establishment. Journal of the Indian Society of Soil Science, 54(1), 12-17.

Joshi, P. K., Birthal, P. S., and Bourai, V. A. 2002. Socioeconomic constraints and opportunities in rainfed rabi cropping in rice fallow areas of India. International Crops Research Institute for the SemiArid Tropics, Patancheru, 502(324), 58.

Kar, G., and Kumar, A. 2009. Evaluation of post-rainy season crops with residual soil moisture and different tillage methods in rice fallow of eastern India. Agricultural Water Management, 96(6), 931-938.

Kumar, N., Ghosh, P. K., Singh, M. K., Hazra, K. K., and Venkatesh, M. S. 2013. Boost rice-fallows chickpea production system in India through suitable soil moisture conservation practices. Indian Institute of Pulse Research,Kanpur.

NAAS 2013. "Improving productivity of rice fallows". Policy Paper No. 64, National Academy of Agricultural Sciences, New Delhi: 16 P.

Reddy, B.N., Babu, S.N.,Sudhakara, Ravishankar, G., Reddy, B., Sahadeva, and Jayaprada, A. 2004. Effect of sowing time on the performance of sunflower (Helianthus annus) cultivars in rice (Oryza sativa) fallow vertisols of the northern Karnataka. Indian Journal of Agronomy. 49(4), 275-277.

Subbarao, G. V., Kumar, R., Kumar, J., Johansen, C., Deb, U. K., Ahmed, I., and Harris, D. 2001. Spatial distribution and quantification of rice-fallows in South Asia: potential for legumes. Spatial distribution and quantification of rice-fallows in South Asia: potential for legumes. 


\section{How to cite this article:}

Nitu Kumari and Badal, P. S. 2020. Socio-Economic Conditions of Farmers in Rice-Fallow Area of Bhagalpur District of Bihar. Int.J.Curr.Microbiol.App.Sci. 9(02): 1217-1223. doi: https://doi.org/10.20546/ijcmas.2020.902.144 